\title{
Utility DSM Rebates For Electronic Ballasts: National Estimates and Market Impact $(1992$ - 1997)
}

\author{
C.B. Busch, B.A. Atkinson, J.H. Eto, \\ I. Turiel, and J.E. McMahon
}

October 2000

\author{
Energy Efficiency Standards Group \\ Energy Analysis Department \\ Environmental Energy Technologies Division \\ Lawrence Berkeley National Laboratory \\ University of California \\ Berkeley, CA 94720
}

For a downloadable version, visit the Energy Analysis Department publications website, http://eetd.lbl.gov/EA/publications.html. 


\section{TABLE OF CONTENTS}

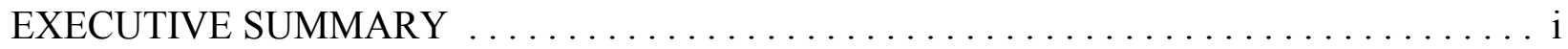

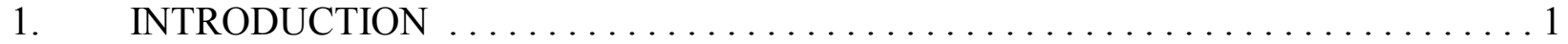

2. GENERAL DEVELOPMENTS IN DSM AND ENERGY EFFICIENCY

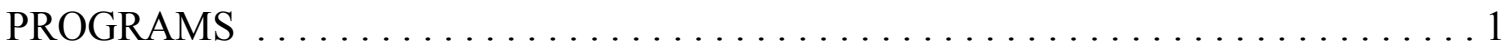

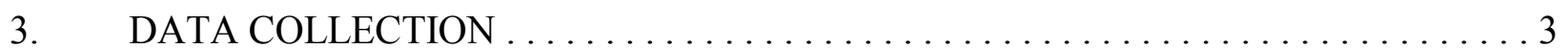

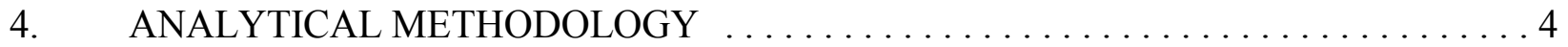

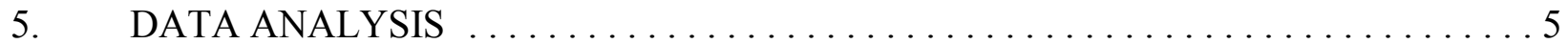

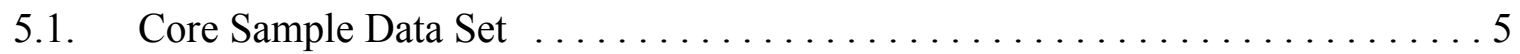

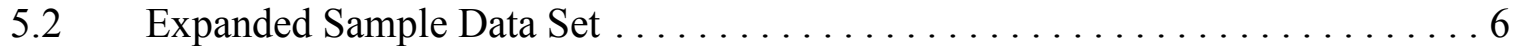

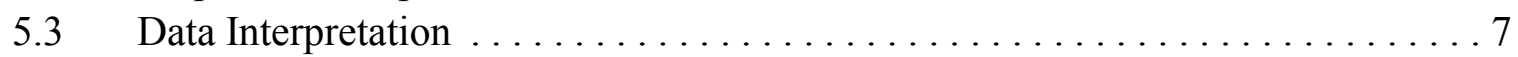

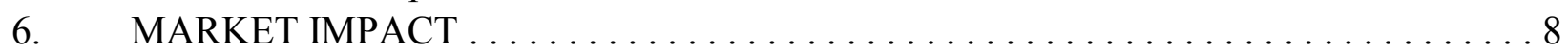

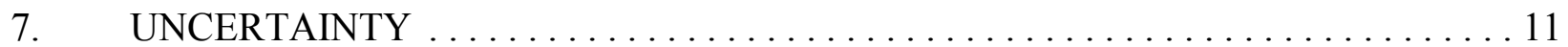

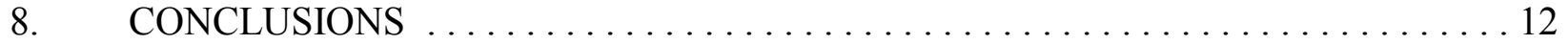

\section{LIST OF TABLES}

Table 1: $\quad$ Total Energy Efficiency Spending of Utilities in the Core and Expanded Sample Data Sets as Percent of the Nation's Total Energy Efficiency Spending . 2 Table 2: $\quad$ Electronic Ballast DSM Rebate Estimates Derived from Core Sample . . . . . . 6 Table 3: $\quad$ Electronic Ballast Rebate Estimates Derived from Expanded Sample . . . . . . . 7

Table 4: $\quad$ Ballast Shipments and Market Share Data .................... 10

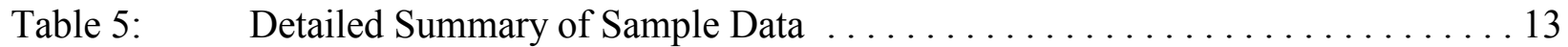

\section{FIGURE}

Figure 1. Ballast Shipment and DSM Rebate Data .......................... 9 


\section{EXECUTIVE SUMMARY}

In this report we present national estimates of utility Demand-Side Management (DSM) rebates for electronic fluorescent lamp ballasts during the period of 1992 - 1997. We then compare these trends with developments in the fluorescent ballast market from 1993 - 1998. The analysis indicates that DSM rebates for electronic ballasts peaked in the mid-1990s and declined sharply in 1996 and 1997. In a parallel trend, electronic ballast sales and market share both increased significantly during 1993 - 1994 and increased more slowly in $1996-1997$.

We analyzed time series data from nine utilities on their DSM electronic ballast rebates from 1992 - 1997. We distinguished two sample data sets, referred to as the core and expanded samples. The core sample data set includes information from six utilities, whose total energy-efficiency spending represented about 17 percent of national utility spending on energy-efficiency programs during that period. The expanded sample data set adds three utilities, which provided partial data, to the core sample. Total energy efficiency expenditures for utilities in the expanded sample accounted for about 30 percent of national expenditures for the period.

Analysis of the core and expanded samples led to the following two national estimates. All dollars have been converted to constant 1997 dollars.

\section{Core Sample Data Set Estimates}

\begin{tabular}{|c|c|c|c|c|c|c|}
\hline Year & 1992 & 1993 & 1994 & 1995 & 1996 & 1997 \\
\hline $\begin{array}{c}\text { Percent of EE \$s to electronic ballast rebates } \\
\text { in the sample }\end{array}$ & $5 \%$ & $8 \%$ & $13 \%$ & $13 \%$ & $8 \%$ & $2 \%$ \\
$\begin{array}{c}\text { National estimate of spending on rebates } \\
\text { (millions of \$s) }\end{array}$ & $\$ 71$ & $\$ 137$ & $\$ 219$ & $\$ 190$ & $\$ 81$ & $\$ 21$ \\
$\begin{array}{c}\text { Average \$/rebate in the sample } \\
\text { nstimated number of rebates nationwide (millions) }\end{array}$ & 15.80 & 14.32 & 11.99 & 12.36 & 7.78 & 3.35 \\
\hline
\end{tabular}

\section{Expanded Sample Data Set Estimates}

\begin{tabular}{|c|c|c|c|c|c|}
\hline Year & 1992 & 1993 & 1994 & 1995 & 1996 \\
\hline Percent of EE \$s to electronic ballast rebates in the sample & $11 \%$ & $6 \%$ & $8 \%$ & $12 \%$ & $5 \%$ \\
National estimate of spending on rebates (millions of \$s) & $\$ 146$ & $\$ 106$ & $\$ 142$ & $\$ 171$ & $\$ 55$ \\
Average \$s/rebate in the sample & 23.04 & 13.06 & 12.04 & 12.36 & 7.78 \\
Estimated number of rebates nationwide (millions) & 6.3 & 8.1 & 11.8 & 13.9 & 7.1 \\
\hline
\end{tabular}

The core sample data set indicates that electronic ballast rebates peaked in 1994 in terms of the number of ballasts rebated and utility spending on rebates. The estimated number of rebates declines steadily from 1995 through 1997 . The expanded data set indicates that rebates and spending peaked 
in 1995 rather than 1994. However, as with the core sample, the analysis points to a substantial drop from 1995 to 1996.

Comparison of the sales of electronic ballasts (for T8 lamps) with these national rebate estimates shows a parallel trend. As rebates for electronic ballasts increased through 1994-95, both numbers and market share of electronic ballasts increased. The trend toward fewer rebates in 1996-1997 parallels a leveling-off of electronic ballast sales, along with a slower rate of increase of the electronic market share. (This trend continued in 1998). However, other factors also influenced the market during this period, and new incentive programs will continue to affect the market. New national fluorescent ballast standards will cause ballasts sold for luminaires (for new and renovated buildings) to be electronic beginning in 2005 , and similarly affect ballasts sold for replacement starting in 2010. 


\section{INTRODUCTION}

This paper analyzes the impact of Demand-Side Management (DSM) programs on the market for electronic fluorescent ballasts in the mid-1990s. Traditionally, utilities have responded to projected growth in demand by building more power plants to increase the electricity supply. In contrast, the Demand-Side Management approach, begun in the late 1980s, aims to decrease the overall system demand by providing incentives to individual consumers to reduce their energy demand and usage. This is typically accomplished by increasing equipment or building efficiency and/or reducing hours of usage. A number of utilities offered programs for fluorescent ballasts used in commercial and industrial buildings, providing rebates for the purchase of high-frequency electronic ballasts in place of the conventional magnetic ballasts. Electronic ballasts have significantly higher initial costs but are more efficient and therefore have lower life-cycle costs than do magnetic ballasts.

The study estimates the annual number of rebates paid for electronic ballasts since their widespread emergence in the early 1990s, the monetary value of these rebates, and the fraction of national ballast sales comprised by the rebated ballasts. The objective was to discern historical trends in DSM rebates and to judge their impact on the market share garnered by electronic ballasts. We present data for the years for which data are available: on utility rebates from 1992 - 1997, on national DSM and energy-efficiency spending from 1992 - 1998, and on national electronic ballast sales from $1993-1998$.

This study was part of the analysis by Lawrence Berkeley National Laboratory (LBNL) for the new national ballast standards published by the Department of Energy (DOE) in September 2000 under the National Appliance Energy Conservation Act (NAECA). These standards effectively mandate electronic ballasts for four-foot and eight-foot fluorescent ballasts for T12 lamps for ballasts in luminaires (for new and renovated buildings) starting in 2005 and for replacement ballasts in 2010. For that study, LBNL also analyzed the potential impacts of other non-regulatory programs on the ballast market (EPA's Green Lights and Energy Star Buildings programs and the Federal Energy Management Program's Procurement Challenge and Federal Relighting Initiative), as well as the impact of the revision of the ASHRAE/IESNA-1999 building code. These programs, as well as other utility and market-based programs, will continue to affect the ballast market until the new NAECA standards take effect for the two market segments. The entire analysis may be found in the Technical Support Document, with non-regulatory impact analysis in Appendix B, at http://www.eren.doe.gov/buildings/codes standards/applbrf/ballast.html.

\section{GENERAL DEVELOPMENTS IN DSM AND ENERGY EFFICIENCY PROGRAMS}

Electric utility DSM programs grew rapidly in the late 1980s and early 1990s due to incentives created by state regulatory commissions to encourage integrated resource planning (Eto 1996). Expenditures on DSM programs peaked in 1993, reaching a level of about 1 percent of electric utility 
revenue or $\$ 3.0^{1}$ billion for the nation (US DOE 1995a). This figure dipped slightly in 1994 , and fell to $\$ 2.5$ billion in $1995, \$ 1.9$ billion in $1996, \$ 1.6$ billion in 1997, and $\$ 1.5$ billion in 1998. (US DOE 1995b; US DOE 1997a; US DOE 1997b; US DOE 1999).

Spending on the Energy Efficiency (EE) component of DSM programs followed a similar path. ${ }^{2}$ EE spending reached a peak in 1993, leveled off, and then declined sharply in 1996. In 1995, EE spending fell by 14 percent from the year before, in 1996 by 28 percent, in 1997 by 16 percent, and in 1998 by 16 percent compared to the previous year. Table 1 lists national spending on EE programs from 1992 - 1998, as well as the percentage of that national total accounted for by the two sample data sets analyzed in this study.

Table 1: Total Energy Efficiency Spending of Utilities in the Core and Expanded Sample Data Sets as Percent of the Nation's Total Energy Efficiency Spending

\begin{tabular}{|c|c|c|c|}
\hline Year & $\begin{array}{l}\text { National EE \$s } \\
\quad(\text { millions })^{*}\end{array}$ & Core Sample (\%) & Expanded Sample (\%) \\
\hline 1992 & 1,345 & 18 & 33 \\
\hline 1993 & 1,748 & 14 & 29 \\
\hline 1994 & 1,690 & 18 & 31 \\
\hline 1995 & 1,462 & 19 & 27 \\
\hline 1996 & 1,057 & 18 & 30 \\
\hline 1997 & 892 & 17 & $\mathrm{NA}^{* *}$ \\
\hline 1998 & 751 & NA & NA \\
\hline Avg (92-97) & & 17 & 30 \\
\hline
\end{tabular}

All dollars are constant \$1997.

" DOE/EIA Annual Reports on DSM, "U.S. Electric Utility Demand-Side Management," for 1993, 1994, 1995, 1996 (Form EIA-861, EIA-0589 93-96) and "Electric Power Annual, Vol. II" for 1997 and 1998. No report was published for 1992; data for the year were provided directly by EIA.

${ }^{* *}$ Not available: none of the three utilities added to the core sample data set provided information on 1997 rebate programs.

Notes on Table 1: The column "National EE \$s" indicates total national DSM expenditures on energy efficiency for each year. The column "Core Sample \%" lists the percentage of national EE expenditures represented by the total energy efficiency spending of the six utilities that comprise the core sample data set. The column "Expanded Sample \%" lists the percentage of national EE expenditures represented by the nine utilities that comprise the expanded sample data set.

The DOE's Energy Information Administration (EIA) reports that electric utilities began to scale back their DSM programs in anticipation of a competitive market. "In the search for cost savings, utilities are reassessing approaches to energy conservation and peak load reduction. In

\footnotetext{
${ }^{1}$ All dollars are constant $\$ 1997$.

${ }^{2}$ In addition to energy efficiency, the other components of DSM programs are: direct load control, interruptible load, and other load management.
} 
many cases, they are opting to discontinue or reduce the emphasis on these DSM programs." (US DOE 1998). The EIA's 1996 annual report on DSM found that 1003 utilities out of 3,199 electric utilities in the nation reported DSM programs in 1996 compared to 1053 in 1995 (US DOE 1997b). Of the 50 utilities discontinuing all DSM programs in 1996, 10 were large and 40 were small electric utilities.

Also, in recent years, utilities have consistently projected higher spending on DSM for the following year than they actually spent. For example, in 1997, actual spending on DSM fell \$417 million short of the level predicted the year before, which was 80 percent of the predicted level of spending. ${ }^{3}$ For 1996, 1995 and 1994, the differences were $\$ 335$ million (with spending as 85 percent of predicted), $\$ 177$ million (92 percent of predicted) and $\$ 306$ million respectively (90 percent of predicted). Similar trends were found in EE spending; actual 1997 spending was 84 percent of that predicted and 1998 spending was 87 percent of predicted.

During this period, only a few states had introduced competition in the electricity market. It seems unlikely that the national declines in EE and DSM spending observed in recent years will reverse as deregulation spreads to more states and more utilities face the cost-minimizing and profitmaximizing demands of a competitive market.

\section{DATA COLLECTION}

We sought to collect as much data as possible on electronic ballast rebates from around the nation. We made data requests to the 15 utilities with the largest DSM programs and 32 utilities overall. Six utilities provided detailed data showing both the number of ballasts installed under rebate measures and the cost of these rebates. The six utilities that comprise the core sample data set are: Central Maine Power Company (ME), the Long Island Lighting Company (NY), Pacific Gas \& Electric (CA), Rochester Gas \& Electric (NY), San Diego Gas and Electric (CA) and one referred to as Utility $\mathrm{X}$ since the utility requested that its identity remain confidential.

As Table 1 illustrates, the total spending on energy efficiency programs of the six utilities in the core sample data set accounted for about 17 percent of national spending on EE programs during the period of this report. Further analysis found that while the 6 utilities comprised only 2 percent of the number of utilities (273 in all) that had EE programs in $1994^{4}$, they accounted for 10 percent of the total revenue and 7 percent of the total electricity sales of that set of utilities (US DOE 1995b, US DOE 1995c).

Three large utilities — Baltimore Gas \& Electric (MD), Southern California Edison (CA), and Consolidated Edison (NY) - also provided data that were useful and extensive, but not as complete

\footnotetext{
${ }^{3}$ Utility projections of DSM spending for the next year and five years later were found in Table 22 of the EIA's annual reports on DSM programs, 1992 - 1996 and in the Electric Power Annual, vol. II, 1997.

${ }^{4}$ As stated below, the peak year for ballast rebates in the core sample was 1994.
} 
as that in the core sample. Baltimore Gas \& Electric provided annual figures on the number of rebated ballasts installed, but not the dollar value of these rebates. Southern California Edison provided data on yearly spending on ballasts, but not the corresponding number of rebated ballasts. Consolidated Edison provided data that involved estimation of the number of electronic ballasts rebated under some measures for each year, and for later years lacked specific information on the value of each rebate. ${ }^{5}$

Using the average rebate value from the core sample data set, we incorporated the information provided by the three additional utilities to create an expanded sample data set. In the case of Southern California Edison, we divided the figures provided on annual expenditures for electronic ballast rebates by the average rebate value from the core sample to estimate the number of ballasts rebated annually (expenditures on electronic ballast rebates, $\$$ s per rebate $=$ total number of electronic ballasts rebated). In the case of Baltimore Gas \& Electric, we multiplied the figures for the annual number of rebates by the average rebate value to estimate the utility's annual spending on electronic ballast rebates (number of rebates $\mathrm{x} \$ \mathrm{~s}$ per rebate $=$ total spending on electronic ballast rebates). For the years for which Consolidated Edison provided information on the number of rebates only, the same approach was used as in the case of Baltimore Gas \& Electric.

As shown in Table 1, the nine utilities included in the expanded data set accounted for about 30 percent of annual national expenditures on EE programs. While the 9 utilities comprised 3 percent of the number of utilities ( 268 in all) that had EE programs in $1995^{6}$, they accounted for 19 percent of the total revenue and 13 percent of the electricity sales of that set of utilities (US DOE 1996, US DOE 1997a).

One data complication arose when utilities offered a rebate for an electronic ballast in combination with a lamp or a fixture. Generally, in the case of such rebate measures, we used the value of the rebate for the ballast alone as a guide. For example, in 1994, Pacific Gas \& Electric offered a $\$ 5$ rebate for an electronic ballast alone or $\$ 6$ for an electronic ballast with T8 lamp. In this case, the total spending on the combined lamp and ballast measure was multiplied by $5 / 6$ to approximate the amount of the rebate attributable to the ballast.

Data collection efforts were hindered by several factors:

- Frequent turn-over in personnel made it difficult to find staff with historical knowledge.

- Many utilities do not keep detailed historical data in readily accessible form; lack of a standardized reporting format made data interpretation challenging.

- Diminishing resources devoted to DSM made individuals still working on DSM less available to respond to requests for data.

\footnotetext{
${ }^{5}$ Some utilities have changed their names or their acronyms since the data were obtained.

${ }^{6}$ As stated below, the peak year for ballast rebates in the core sample was 1995 .
} 
- In one case, the utility did not provide data despite state regulations requiring that the data be made available upon request.

\section{ANALYTICAL METHODOLOGY}

Our first set of estimates is based on analysis using only the core sample data set. We used two values derived from the core sample to estimate the number of electronic ballasts for the nation and their dollar value annually for the years 1992 to 1997 . First, we calculated the fraction of energy efficiency spending devoted to electronic ballast rebates and the average value of the rebate per ballast for the sample data. Next, we assumed that the average rebate value and fraction of EE spending going to ballast rebates was the same for the nation as in the sample. For each year, we multiplied nationally-aggregated energy efficiency spending by the fraction of EE spending going to ballast rebates in the sample to estimate national spending on ballast rebates. Then, we divided this estimate of spending on ballast rebates by the average rebate per ballast to estimate the number of ballasts rebated for the year.

$$
\begin{aligned}
& \text { National Ballast Rebates (ballasts) }=\frac{\text { National Rebate } \$ s \text { to ballasts }}{\text { Average Rebate in Sample (\$ per ballast) }} \text {, } \\
& \text { where: } \quad \text { National Rebate } \$ \text { s to ballasts }= \\
& \text { Percent EE } \$ \text { s to Ballast Rebates in Sample * National EE } \$ S
\end{aligned}
$$

For example, in 1994, the six utilities in the core sample spent about $\$ 297$ million on energy efficiency programs and $\$ 39$ million on ballast rebates, so the ballast rebates represented almost 13 percent of total EE spending for the sample. The \$39 million was distributed among about 3.2 million ballasts, for an average expenditure of approximately $\$ 12$ per ballast in 1994 . Nationally, EE programs amounted to about $\$ 1.69$ billion in 1994, so we estimated that electronic ballast rebates were about $\$ 219$ million (11 percent of $\$ 1.69$ billion) for the year. Based on an average value of $\$ 12$ per rebate, we estimated that about 18.3 million ballasts ( $\$ 219$ million divided by $\$ 12 /$ ballast) were installed under DSM rebate measures in 1994.

We calculated a second set of estimates using the expanded data set. For the years 19921994, we calculated a new average rebate value for the sample using Consolidated Edison's data. ${ }^{7}$ For the other years, we used the average rebate value from the core sample data set to fill out the information provided by the three extra utilities in the expanded sample (see the previous section for a detailed explanation of this process). Then, using the same approach, we calculated the percentage of energy efficiency spending going to electronic ballast rebates in the sample. We applied this

\footnotetext{
${ }^{7}$ ConEd was excluded from the core sample data set for 1992-1994 because for each year some measures reported by Con Ed included estimates of ballast rebates rather than actual figures. Although our contact at Con Ed thought that fairly reliable estimates could be made, uncertainty about the precision of estimates led us to include all the Con ED data in the expanded sample data set rather than the core.
} 
percentage to national energy efficiency spending in order to calculate an estimate of national expenditures on electronic ballast rebates. Then, we estimated the number of ballasts rebated nationwide by dividing the estimate of national electronic ballast rebate expenditures by the average rebate per ballast.

\section{DATA ANALYSIS}

\subsection{Core Sample Data Set}

Using the methodology described above and the core sample data set, we calculated the following national estimates of the number of electronic ballast DSM rebates and spending on these rebates.

Table 2: Electronic Ballast DSM Rebate Estimates Derived from Core Sample

\begin{tabular}{|c|c|c|c|c|c|c|}
\hline Year & 1992 & 1993 & 1994 & 1995 & 1996 & $1997^{*}$ \\
\hline $\begin{array}{c}\text { Percent of EE \$s to electronic ballast rebates in the } \\
\text { sample }\end{array}$ & $5 \%$ & $8 \%$ & $13 \%$ & $13 \%$ & $8 \%$ & $2 \%$ \\
National estimate of spending on rebates (millions & $\$ 71$ & $\$ 137$ & $\$ 219$ & $\$ 190$ & $\$ 81$ & $\$ 21$ \\
of \$s) & & & & & & \\
Average \$/rebate in the sample & 15.80 & 14.32 & 11.99 & 12.36 & 7.78 & 3.35 \\
Estimated number of rebates nationwide (millions) & 4.5 & 9.6 & 18.3 & 15.4 & 10.5 & 6.3 \\
\hline
\end{tabular}

All dollars are constant \$1997.

* 1997 estimates based on data for $1 / 2$ to $3 / 4$ of the year, as described below.

Notes on Table 2: The estimate of the number of rebates nationwide, listed in the fourth row, results from dividing the estimate of national spending on rebates in the second row by the weighted average rebate value found in the third row (row four $=$ row two $/$ row three). The national estimate of spending on electronic ballast rebates in the second row results from multiplying national spending on rebates (listed in Table 1) by the fraction of energy efficiency dollars going to rebates listed in the first row.

The results of this analysis suggest that electronic ballast rebates peaked in 1994 in terms of the number of ballasts rebated as well asd utility spending on rebates. The estimated number of rebates declined steadily from 1995 through 1997. In 1996, our analysis suggests that the number of rebates fell by 32 percent and that spending on electronic ballast rebates fell by 57 percent from the year before. In 1997, the number of rebates fell by 40 percent and utility expenditures on rebates fell by 74 percent. However, data analysis for 1997 is less certain because the sample data set includes data for less than the full year. Between 6 months and 10 months of utility data were used to estimate the number of ballasts rebated and spending on these rebates for the year.

The trend that this analysis identifies, a reduction in incentives provided by electronic ballast DSM rebates since 1994, is supported by the decision of two of the smaller utilities in the sample to end their electronic ballast rebate programs in recent years. In 1995, the Central Maine Power 
Company stopped offering electronic ballast rebates. Rochester Gas \& Electric ended their incentives program for ballasts in 1996.

\subsection{Expanded Sample Data Set}

Using the expanded data set, we calculated a second set of national estimates of the number of electronic ballasts rebated and spending on these rebates.

Table 3: Electronic Ballast Rebate Estimates Derived from Expanded Sample

\begin{tabular}{|c|c|c|c|c|c|}
\hline Year & 1992 & 1993 & 1994 & 1995 & 1996 \\
\hline \% of EE \$s to electronic ballast rebates in the sample & $11 \%$ & $6 \%$ & $8 \%$ & $12 \%$ & $5 \%$ \\
National estimate of spending on rebates (millions of \$s) & $\$ 146$ & $\$ 106$ & $\$ 142$ & $\$ 171$ & $\$ 55$ \\
Average \$s/rebate in the sample & 23.04 & 13.06 & 12.04 & 12.36 & 7.78 \\
Estimated number of rebates nationwide & 6.3 & 8.1 & 11.8 & 13.9 & 7.1 \\
\hline
\end{tabular}

All dollars are constant $\$ 1997$.

Notes on Table 3: The estimate of the number of rebates nationwide, listed in the fourth row, results from dividing the estimate of national spending on rebates in the second row by the weighted average rebate value found in the third row (row four = row two / row three). The national estimate of spending on electronic ballast rebates in the second row results from multiplying national spending on rebates (listed in Table 1) by the fraction of energy efficiency dollars going to rebates listed in the first row. Recall that none of the utilities added to the core sample were able to provide any information on 1997. Thus, there is no expanded sample estimate for that year.

Analysis of the expanded sample data set suggests that DSM rebates for electronic ballasts peaked in 1995 rather than 1994. Despite this difference, estimates from the expanded sample generally support the pattern that emerged from analysis of the core sample. In 1996, for this sample the number of rebates fell by 49 percent and spending on electronic ballast rebates fell by 68 percent. We did not prepare estimates for 1997, since none of the utilities that were added to the core sample to create the expanded sample provided data for that year.

One notable aspect of the expanded sample data set is the larger value calculated for the weighted average value per rebate in 1992. This reflects the fact that Consolidated Edison rebated over 1 million ballasts for the year for $\$ 28$ to $\$ 39$ per ballast (depending on the number of lamps per ballast). Consolidated Edison's electronic ballast rebates accounted for more than 40 percent of the ballast rebates in the expanded sample for 1992. By the following year, the utility's rebate levels were more similar to others in the sample, ranging from $\$ 7$ to $\$ 16$ per ballast.

\subsection{Data Interpretation}

Since the core sample data set contains actual reported data, we consider that the core sample estimates may be more reliable than those from the expanded sample. As explained above in Data Collection (section 3), the expanded sample estimates have some data derived from those reported 
by the utilities, calculated by using the average rebate value from the core sample data set. Thus the core sample estimates contain fewer extrapolations and assumptions than the expanded sample estimates, although they represent a smaller proportion of the utility population.

We note that the decrease in spending on electronic ballast rebates fell much more sharply than did total utility spending on all energy-efficiency programs in the later analysis years (see Tables 1 and 2). In the core sample, rebate spending in 1996 fell to less than half of 1995 rebate spending, and in the expanded sample it fell to one-third of its 1995 level. In contrast, national energyefficiency spending in 1996 decreased to only about three-quarters of its 1995 level. This may indicate that utilities have been eliminating their rebates for ballasts, or for lighting equipment, more rapidly than those for other energy-efficient technologies.

\section{MARKET IMPACT}

Here we combine this study's national electronic ballast DSM rebate estimates with data provided by the National Electrical Manufacturers Association (NEMA) on domestic U.S. ballast shipments to gain some insight into the impact of DSM programs on the ballast market. In particular, we examine the impact of the reduction in the number of DSM rebates for electronic ballasts on the shipments and market share of electronic ballasts with respect to magnetic ballasts for T12 lamps (which were the large majority of ballasts sold before 1992). The shipments data include ballasts operating both four-foot and eight-foot lamps. While it was not possible for our DSM rebate estimates to be disaggregated into to those operating T8 and T12 lamps, we expect that most electronic ballast rebates for four-foot lamps were for T8 lamps, usually replacing magnetic ballasts for T12 lamps.

Figure 1 presents shipments of T12 magnetic ballasts and electronic ballasts in the U.S. as reported by NEMA ${ }^{8}$ along with the DSM rebate estimates derived from the core sample data set and the expanded sample data set. Note that the 1997 values for rebates in Figure 1 are based on incomplete data for that year.

Figure 1 shows the number of electronic ballast shipments rising from 1993 to 1995 . In 1996 the number of electronic ballast shipments falls slightly, while the total number of ballasts shipments also falls. In 1997 and 1998 the electronic ballast shipments increase again, as do the total number of shipments. However, the increase during this period is not as rapid as in the earlier period. The figure suggests some correlation between DSM rebates and electronic ballast shipments. As rebates for electronic ballasts were on the increase, the number of electronic ballast shipments was rising more rapidly. As the rebates decreased, the growth in electronic shipments slowed down. However, correlation does not provide a basis for judging causation, and other factors may also have been determinants of the trend in shipments.

\footnotetext{
${ }^{8}$ These shipments data are for ballast types covered by the upcoming revised NAECA ballast standards described below; they do not include dimming ballasts, residential ballasts, and other excluded ballast types.
} 
Table 4 shows the shares of electronic ballasts represented by the rebated ballasts in the core and expanded samples. Both sets of data indicate that a significant fraction of all electronic ballasts purchased received rebates. On average for the analysis periods, this share (\% of Electronic Ballasts with Rebates) is 41 percent for the core sample and 37 percent for the expanded sample. The share is higher in the earlier years for both samples, reaching a peak in 1994 of 70 percent for the core sample and 45 percent for the expanded sample. By 1996 the share of electronic ballasts receiving rebates falls to 35 percent for the core sample and 24 percent for the expanded sample. By 1997 the core sample share is only 18 percent.

Table 4 also reports the annual number of electronic ballast shipments and their percentage of total shipments (market share). Data on market share reveal a similar pattern to data on the number of shipments. Table 4 shows that the shares of the total market held by electronic ballasts increased from 1993 to 1995 when rebates for electronic ballasts were on the rise. A slowdown in the rate of increase of electronic ballast market share similar to that of the electronic ballast shipments can be seen in later years. The electronic share remained almost unchanged from 1995 to 1996 and increased more slowly in 1997, during the time when ballast rebates were on the wane. This indicates the potential impact of the disappearance of rebate programs. However, the slowdown in the growth of the electronic ballast market share may or may not reveal a long-term trend. (Note in Table 4 that total ballast shipments dipped in 1996, while rising steadily during the years prior and after.) 


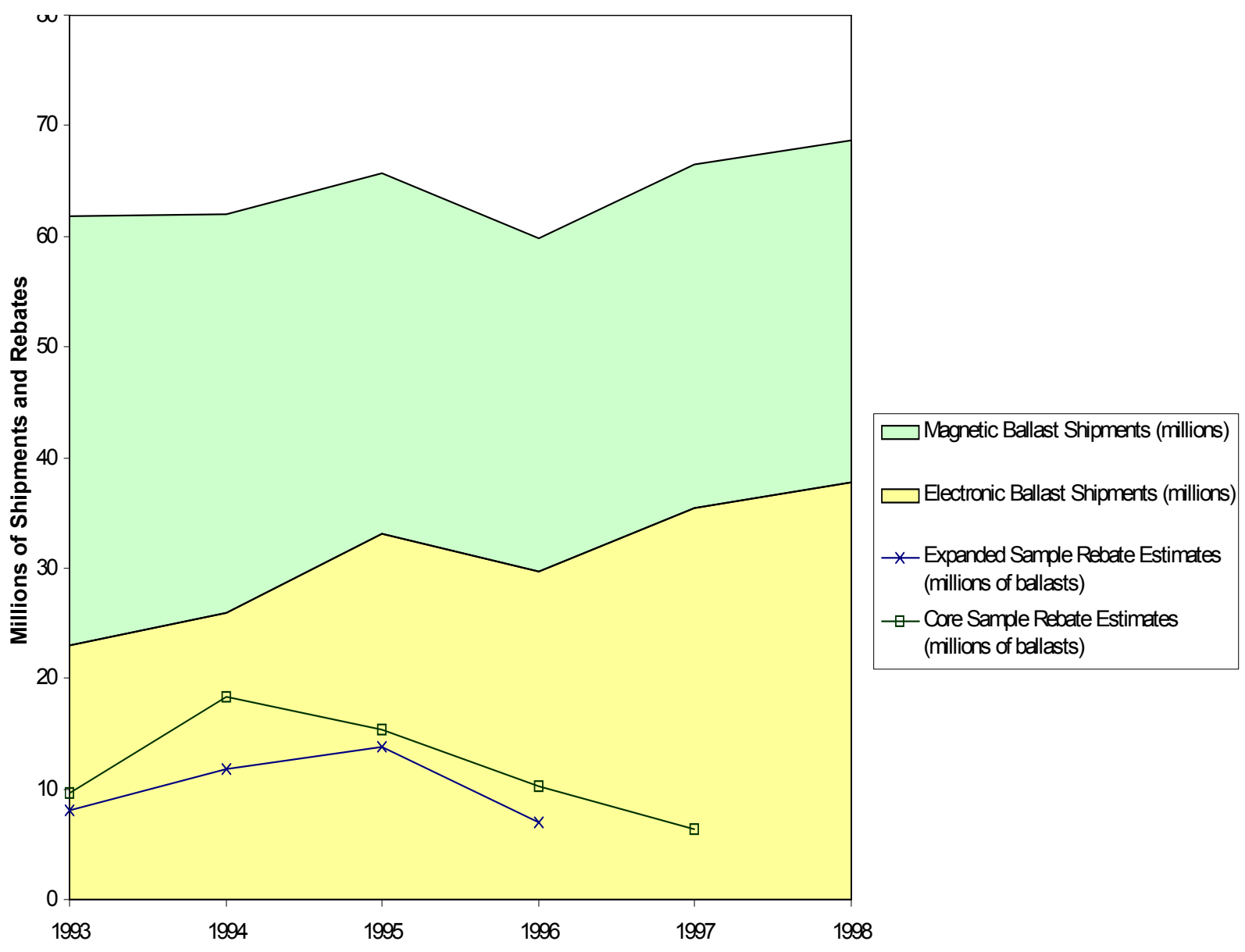

Figure 1. Ballast Shipments and DSM Rebates 
Table 4: Ballast Shipments and Market Share Data

\begin{tabular}{|l|c|c|c|c|c|c|c|}
\hline & $\mathbf{1 9 9 3}$ & $\mathbf{1 9 9 4}$ & $\mathbf{1 9 9 5}$ & $\mathbf{1 9 9 6}$ & $\mathbf{1 9 9 7}$ & $\mathbf{1 9 9 8}$ & Avg. \\
\hline Magnetic Ballast Shipments (millions) & 39.0 & 36.0 & 32.7 & 30.1 & 31.1 & 30.9 & NA \\
Electronic Ballast Shipments (millions) & 22.9 & 26.0 & 33.1 & 29.7 & 35.4 & 37.8 & NA \\
Total Ballast Shipments (millions) & 61.9 & 62.0 & 65.8 & 59.8 & 66.5 & 68.7 & NA \\
Electronic Ballast Market Share (\% of & $37 \%$ & $42 \%$ & $50 \%$ & $50 \%$ & $53 \%$ & $55 \%$ & NA \\
$\begin{array}{l}\text { Ballast Market) } \\
\text { Core Sample Rebate Estimates (millions) }\end{array}$ & 9.6 & 18.3 & 15.4 & 10.5 & 6.3 & NA & NA \\
$\begin{array}{l}\text { Core Sample \% of Electronic Ballast } \\
\text { with Rebates }\end{array}$ & $42 \%$ & $70 \%$ & $46 \%$ & $35 \%$ & $18 \%$ & NA & $41 \%$ \\
$\begin{array}{l}\text { Expanded Sample Rebate Estimates } \\
\text { (millions) }\end{array}$ & 8.1 & 11.8 & 13.9 & 7.1 & NA & NA & NA \\
$\begin{array}{l}\text { Expanded Sample \% of Electronic } \\
\text { Ballasts with Rebates }\end{array}$ & $36 \%$ & $45 \%$ & $42 \%$ & $24 \%$ & NA & NA & $37 \%$ \\
\hline
\end{tabular}

Shipments data provided by NEMA.

NA $=$ Not estimated.

Comments: Data are for ballasts operating both 4-foot and 8-foot lamps. Almost all magnetic ballasts sold were for T12 lamps.

If we assume that consumers respond at least to some extent to the lower net purchase prices that result from ballast rebates, then the decreasing availability of DSM rebates for electronic ballasts may have contributed to the slowdown in the electronic market share. However, the increased product demand stimulated by rebates may have induced lasting market price decreases for electronic ballasts. Also, the increased usage of electronic ballasts may have accelerated the development of the technology and increased quality and reliability, making it more acceptable to end-users. Thus, the increased usage of electronic ballasts due to rebates may have had a transformative effect on the ballast market that could persist after the decline of the rebates.

DSM rebates do not influence the market in a vacuum and other variables have not been considered in this study. Rebates are of one of several interrelated factors that determine the extent of market penetration over time for any particular product. While DSM rebates have been diminishing, other non-regulatory programs that provide incentives to switch to electronic ballasts have remained in place or grown. These include the EPA Green Lights/Energy Star Buildings programs, the Federal Energy Management Program's Procurement Challenge and Federal Relighting Initiative, and other initiatives such as NEMA's Energy Cost Savings Council/ReElectrify America. The ASHRAE/IES 90.1 building code is being adopted by states under EPAct. The code's revised version, which has lower limits on lighting Watts/square foot that are based on the assumption of the use of electronic ballasts, will be in place in the early 2000s. Energy service companies also promote the installation of electronic ballasts; some of their programs are supported by utilities. New energy-efficiency programs will arise through state deregulation plans that include 
public benefit funds for energy efficiency programs, and the federal government may provide matching funds.

All of the above-mentioned programs may have some countervailing impacts to the disappearance of ballast rebates in the near term. Beginning in 2005, the ballast market will be most dramatically affected by the upcoming NAECA ballast efficiency standards, which require the efficiency levels of electronic ballasts. These standards will take effect for ballasts sold by manufacturers for use in luminaires in 2005 (for new and renovated buildings), for ballasts in luminaires by 2006, and for ballasts for the replacement market in 2010. The luminaire market comprises the majority of ballast sales and more than half of those ballasts were electronic in 1998. The replacement market was nearly all magnetic ballasts; therefore this market offers considerable opportunities for non-regulatory program incentives for electronic ballast retrofits for the next ten years.

\section{UNCERTAINTY}

We are confident of the general trend identified by this analysis: DSM rebates for electronic ballasts increased in number from 1992 to 1994 or 1995, when they began to decline in number. All of the sample data collected shows utilities reducing or eliminating their DSM rebates for electronic ballasts in 1996 or 1997 . Thus, the sample data parallels the general national trend toward smaller DSM programs, as discussed above. A detailed summary of the sample data is provided in Table 5 at the end of this section so that the reader can observe the variation and trends over time for the individual utilities.

However, we were able to collect robust data for samples that represent only a fraction of national DSM spending on electronic ballasts. The core sample represents about 17 percent of national expenditures on energy efficiency; the expanded sample accounts for about 30 percent of national expenditures on energy efficiency. The sample size is important because observations from the sample data are scaled up based on national energy efficiency spending to estimate the number of DSM rebates for electronic ballasts for the US as a whole. The estimation technique makes two major assumptions: that the average rebate value and the fraction of energy efficiency spending on rebates calculated for the sample are the same as those for the United States as a whole. The amount of divergence between the assumed values from either sample and the actual national values is uncertain.

Generally, our attempts to increase the sample size were frustrated by the inability of utilities to provide historical data, and some utilities had trouble providing more recent data. Long Island Lighting Company was unable to provide data for 1996 or 1997, thus reducing the core sample by one large utility for those years and exacerbating the small sample size problem. Moreover, none of the additional utilities in the expanded sample were able to deliver any information on 1997. 
We cannot conclusively assess the relative accuracy of the two samples used in the analysis. The expanded sample allows the analysis to incorporate some additional information - the number of ballasts rebated by Baltimore Gas \& Electric and Consolidated Edison, and spending on ballast rebates by Southern California Edison -- but it also requires an additional assumption that each additional utility offered rebates at the value calculated for the core sample.

There are two reasons that this study may underestimate the impact of DSM rebates on the market (Eto et al. 1994; Eto et al. 1995):

(2) Participant spillover effect

Participant spillover, or the "free driver" effect, refers to the lasting impact on those who have taken advantage of rebates. Even if rebates are no longer available, these participant are more likely to buy electronic ballasts in the future because any doubts or uncertainty about the new technology have been dispelled.

(3) Non-participant spillover effect

Non-participant spillover means that lower prices would likely follow from the expanded demand and supply that rebates cause. In turn, these lower prices will likely encourage some additional consumers to purchase electronic ballasts even if they don't receive rebates.

While the two spillover effects cited above lead to the conclusion that the estimates in this study may underestimate the impact of DSM rebates, the presence of a "free rider" effect suggests the opposite (Eto et al. 1994; Eto et al. 1995). The "free rider" principle recognizes that some consumers who purchase electronic ballasts and receive a rebate would have purchased them even if the rebate had not been offered. This study does not resolve which of these two countervailing forces is greatest.

\section{CONCLUSIONS}

During the period of high DSM rebate spending for electronic ballasts from 1992 to 1994 or 1995, the shipments and market share of electronic ballasts increased significantly. In 1996 and 1997, as utility spending on ballast rebates fell, shipments as well as market share of electronic ballasts continued to increase, but grew more slowly.

This study does not predict whether the electronic ballast market share will remain steady or will increase. If it does increase, the market may have been partially transformed by rebates. Other non-regulatory programs may also increase the market share of electronic ballasts. The ballast standards are certain to permanently impact the market, beginning with ballasts for new and renovated buildings starting in 2005, and increasingly affecting the replacement ballast market for which standards will take effect in 2010. 
Table 5: Detailed Summary of Sample Data

\begin{tabular}{|c|c|c|c|c|c|c|}
\hline Year & 1992 & 1993 & 1994 & 1995 & 1996 & 1997 \\
\hline \multicolumn{7}{|c|}{ CORE SAMPLE DATA SET } \\
\hline \multicolumn{7}{|c|}{ (1) Central Maine Power Company } \\
\hline \# of rebates & 44,641 & 52,687 & 53,895 & 0 & 0 & 0 \\
\hline \$s/rebate & 19.21 & 21.63 & 25.44 & 0 & 0 & 0 \\
\hline$\%$ of $\mathrm{EE} \$ \mathrm{~s}$ & $6 \%$ & $9 \%$ & $14 \%$ & 0 & 0 & 0 \\
\hline \multicolumn{7}{|c|}{ (2) Long Island Lighting Company } \\
\hline \# of rebates & 76,515 & 100,397 & 93,574 & 98,029 & $\mathrm{NA}^{*}$ & NA \\
\hline \$s/rebate & 11.52 & 14.58 & 11.93 & 9.39 & NA & NA \\
\hline$\%$ of EE $\$ s$ & $4 \%$ & $6 \%$ & $7 \%$ & $7 \%$ & NA & NA \\
\hline \multicolumn{7}{|c|}{ (3) Pacific Gas \& Electric } \\
\hline \# of rebates & 333,801 & 659,643 & $2,346,229$ & $1,485,346$ & $1,318,372$ & 944,104 \\
\hline \$s/rebate & 7.42 & 6.16 & 5.56 & 5.16 & 4.60 & $2.02^{\mathrm{a}}$ \\
\hline$\%$ of EE $\$ s$ & $2 \%$ & $4 \%$ & $10 \%$ & $8 \%$ & $8 \%$ & $2 \%$ a \\
\hline \multicolumn{7}{|c|}{ (4) Rochester Gas \& Electric } \\
\hline \# of rebates & 25,081 & 41,549 & 55,470 & 16,464 & 0 & 0 \\
\hline \$s/rebate & 13.60 & 11.98 & 9.83 & 5.88 & 0 & 0 \\
\hline$\%$ of $\mathrm{EE} \$ \mathrm{~s}$ & $4 \%$ & $5 \%$ & $7 \%$ & $2 \%$ & 0 & 0 \\
\hline \multicolumn{7}{|c|}{ (5) San Diego Gas \& Electric } \\
\hline \# of rebates & 261,408 & 356,251 & 304,229 & 645,699 & 304,067 & 48,000 \\
\hline \$s/rebate & 22.80 & 21.14 & 20.94 & 20.74 & 13.57 & $13.60^{\mathrm{b}}$ \\
\hline$\%$ of EE $\$ s$ & $17 \%$ & $29 \%$ & $21 \%$ & $34 \%$ & $9 \%$ & $2 \% \mathrm{~b}$ \\
\hline \multicolumn{7}{|c|}{ (6) Utility X (requested anonymity) } \\
\hline \# of rebates & 87,852 & 169,654 & 358,098 & 695,679 & 248,959 & 103,369 \\
\hline \$s/rebate & 14.01 & 20.56 & 21.02 & 18.60 & 16.53 & $10.71^{\mathrm{c}}$ \\
\hline$\%$ of EE $\$ s$ & $6 \%$ & $7 \%$ & $8 \%$ & $13 \%$ & $9 \%$ & $4 \%{ }^{\mathrm{c}}$ \\
\hline \multicolumn{7}{|c|}{ EXPANDED SAMPLE DATA SET } \\
\hline \multicolumn{7}{|c|}{ (7) Baltimore Gas \& Electric } \\
\hline \# of rebates & 166,520 & 221,267 & 347,333 & 699,129 & 185,434 & NA \\
\hline$\$ s /$ rebate $^{\mathrm{d}}$ & 14.16 & 13.18 & 9.34 & 11.91 & 7.64 & NA \\
\hline$\%$ of EE $\$ s$ & $14 \%$ & $10 \%$ & $11 \%$ & $23 \%$ & $5 \%$ & NA \\
\hline \multicolumn{7}{|c|}{ (8) Consolidated Edison } \\
\hline \# of rebates & $1,064,242$ & 617,986 & 81,592 & 88,387 & 66,725 & NA \\
\hline \$s/rebate ${ }^{\mathrm{e}}$ & 26.87 & 8.79 & 13.26 & 11.91 & 7.64 & NA \\
\hline$\%$ of EE $\$ s$ & $30 \%$ & $5 \%$ & $1 \%$ & $3 \%$ & $1 \%$ & NA \\
\hline \multicolumn{7}{|c|}{ (9) Southern California Edison } \\
\hline$\#$ of rebates ${ }^{f}$ & 24,700 & 110,006 & 48,485 & 13,148 & 12,267 & NA \\
\hline$\$$ s/rebate ${ }^{g}$ & 14.16 & 13.18 & 9.34 & 11.91 & 7.64 & NA \\
\hline$\%$ of EE $\$ s$ & $0.6 \%$ & $1.4 \%$ & $0.5 \%$ & $0.4 \%$ & $0.2 \%$ & NA \\
\hline
\end{tabular}

$\%$ of EE $\$ \mathrm{~s}=$ ballast rebates as a percent of total energy-efficiency spending for that utility. 


\section{NOTES ON Table 5: All figures are in current dollars (raw data).}

Source: All data provided directly by utilities, except as noted below.

- $\quad$ NA: Not Available

a 1997 figures estimated using data through 15 October 1997.

b 1997 figures estimated using data through 1 July 1997.

c 1997 figures estimated using data through 1 October 1997.

d These values are taken from the weighted average value calculated for the core sample.

e Values for 1995 and 1996 taken from weighted average value calculated for the core sample. For those years the utility provided estimates of the number of ballasts rebated, but not the corresponding expenditures.

$\mathrm{f}$ The number of rebates is estimated using the figures on yearly spending on ballast rebates provided by SCE and the average rebate value calculated for the core sample.

$\mathrm{g}$ These values are taken from the weighted average value calculated for the core sample.

\section{ACKNOWLEDGMENTS}

We are grateful for the assistance of Scott Logan at the California Public Utilities Commission. We are also grateful for the assistance of those utilities officials who provided the data needed to undertake this study: Fred Ornstein of Consolidated Edison of New York, Lou Debrino and Ann Clark of Long Island Lighting Company, Don Arambula of Southern California Edison, Sheldon Switzer of Baltimore Gas \& Electric, April Gordon of Pacific Gas \& Electric, Jon Vencil and Rob Rubin of San Diego Gas \& Electric, David Saunders of Central Maine Power Co., and Linda Wilson of Rochester Gas \& Electric. We thank Jon Koomey and Ed Vine of Lawrence Berkeley National Laboratory's Energy Analysis Department, Marvin Horowitz of Demand Research and Mitch Rosenberg of Xenergy Inc. for their reviews. We also thank Andrea Denver, Diane Fisher, and Jiang Lin of the Energy Analysis Department, who provided useful comments.

This work was supported by the Office of Building Research and Standards, Office of Energy Efficiency and Renewable Energy, U.S. Department of Energy under Contract Number DE-AC0376 SF00098. 


\section{REFERENCES}

Eto, Joseph. 1996. "The Past, Present, and Future of U.S. Utility Demand-Side Management Programs.” Revue d l’Energie. 483:626-638. December, 1996.

Eto, J., S. Kito, L. Shown, and R. Sonnenblick. 1995. "Where Did the Money Go? The Cost and Performance of the Largest Commercial Sector DSM Programs." The Energy Journal. 21(2)23-49. 2000.

Eto, J., E. Vine, L. Shown, R. Sonnenblick, and C. Payne. 1994. "The Cost and Performance of Utility Commercial Lighting Programs.” The Energy Journal. 17(1):31-51. 1996.

US DOE, U.S. Department of Energy. 1995a. U.S. Electric Utility Demand-Side Management Programs, 1993. EIA, Energy Information Administration. DOE/EIA-0589(93). July.

US DOE, U.S. Department of Energy. 1995b. U.S. Electric Utility Demand-Side Management Programs, 1994. EIA, Energy Information Administration. DOE/EIA-0589(94). December.

US DOE, U.S. Department of Energy. 1995c. Electric Sales and Revenue, 1994. EIA, Energy Information Administration. DOE/EIA-0540(94). November.

US DOE, U.S. Department of Energy. 1996. Electric Sales and Revenue, 1995. EIA, Energy Information Administration. DOE/EIA-0540(95). December.

US DOE, U.S. Department of Energy. 1997a. U.S. Electric Utility Demand-Side Management Programs, 1995. EIA, Energy Information Administration. DOE/EIA-0589(95). July.

US DOE, U.S. Department of Energy. 1997b. U.S. Electric Utility Demand-Side Management Programs, 1996. EIA, Energy Information Administration. DOE/EIA-0589(96). December.

US DOE, U.S. Department of Energy. 1998. "Demand-Side Management Programs: Utilities Shift Focus, Reduce Spending." U.S. Electric Utility Demand-Side Management Programs, 1996. EIA, Energy Information Administration, Press Release. January 7.

US DOE, U.S. Department of Energy. 1999. US Electric Utility Demand-Side Management Program Costs (eia.doe.gov/cneaf/electricity/dsm98/table14.htm). 